\title{
Laser ablating the stable Si isotope budget of slab dehydration
}

\author{
SONJA GEILERT ${ }^{1}$, ELMAR ALBERS ${ }^{2}$, DANIEL A. \\ FRICK $^{3}$, CHRISTIAN HANSEN ${ }^{2}$ AND FRIEDHELM VON \\ BLANCKENBURG ${ }^{3,4}$
}

${ }^{1}$ GEOMAR Helmholtz Centre for Ocean Research Kiel

${ }^{2}$ MARUM - Center for Marine Environmental Sciences, University of Bremen

${ }^{3}$ GFZ German Research Centre for Geosciences

${ }^{4}$ Freie Universität Berlin

Presenting Author: sgeilert@geomar.de

Deep-rooted mud volcanism at the Mariana forearc provides a unique natural laboratory to study slab dehydration in an active subduction zone. Here, fluids are being released from the subducting slab in response to prograde metamorphic conditions at depth. Ascending fluids cause the alteration and serpentinization of ultramafic rocks in the mantle wedge, some of which are subsequently transported to the forearc seafloor via mud volcanism. To test if the serpentinites would record the fluid composition and thus the dehydration reactions in the slab, we investigated silicon $(\mathrm{Si})$ isotopic compositions $\left(\delta^{30} \mathrm{Si}\right)$ of serpentine by in-situ femtosecond LA-ICP-MS. Our samples were recovered during IODP Expedition 366 and originate from three mud volcanoes that root in different depths-the pressure/temperature conditions in their source regions hence vary and so do the main fluid sources. The ultramafic clasts underwent different serpentinization events under changing water/rock ratios, resulting in several distinct serpentine generations. To corroborate our results, we analyzed olivine that was serpentinized under laboratory conditions.

The $\delta^{30} \mathrm{Si}$ values vary strongly between the mud volcanoes but also between early and late serpentine generations within individual samples. Early serpentine that formed under low water/rock ratios has $\delta^{30} \mathrm{Si}$ similar to pristine olivine, in accordance with our experimental findings. In contrast, late serpentine veins that formed under higher water/rock ratios show large ranges in $\delta^{30} \mathrm{Si}$ that differ significantly but systematically between the mud volcanoes, thus with the metamorphic grade at depth. With increasing depth-to-slab, $\delta^{30} \mathrm{Si}$ of such serpentine veins are $-0.10 \%,-1.94 \%$, and $-0.80 \%$ to $-0.93 \%$, respectively. We interpret these across-forearc changes to record the $\mathrm{Si}$ isotopic compositions of the fluid sources, namely the dehydration of (biogenic) opal and release of pore fluids (shallow depth, at inferred slab temperatures of $\sim 80^{\circ} \mathrm{C}$ ), clay mineral breakdown (intermediate depth, $\sim 150^{\circ} \mathrm{C}$ ), and decomposition of clay minerals and altered oceanic crust $\left(>250^{\circ} \mathrm{C}\right)$. These data implicate that $\mathrm{Si}$ isotopic compositions of wedge serpentinites can be used as a reliable proxy for slab dehydration processes. Applying this proxy in paleo-forearc systems should help to unravel the changes in oceanic sediment and the evolution of silica biomineralization through geological time. 